\title{
A TRADITIONAL AND MODERN EDUCATION SYSTEM OF PONDOK PESANTREN IN PERSPECTIVE PHILOSOPHY OF EDUCATION
}

\author{
Rifqi Silfiana \\ Postgraduate of IAIN Salatiga, Email: silfiana.rifqi@gmail.com
}

\begin{abstract}
ABSTRAK
Filsafat dan pendidikan memiliki hubungan yang sangat erat sehingga sudah sewajarnya pemikir-pemikir filsafat memberikan tanggapan terhadap berbagai permasalahan mengenai pendidikan, tidak terkecuali dengan sistem pendidikan di pesantren. Jurnal ini dimaksudkan untuk membedah dan mengupas sistem pendidikan pondok pesantren baik pesantren tradisional maupun pesantren modern. Mencari landasan filsafat di dalamnya agar mampu memahami makna terdalam dari suatu sistem pendidikan di pesantren. Pesantren tradisional menyelenggarakan pendidikan Islam non-klasikal dengan metode bandongan dan sorogan dalam mengkaji kitab-kitab klasik (kitab kuning) oleh ulama-ulama abad pertengahan. Paradigma berpikirnya didominasi oleh term-term klasik, seperti tawadlu' yang berlebihan, zuhud, qanâ'ah, barakah atau akhirat oriented. Pesantren tradisional berpandangan filsafat perenialisme idealism, dan esensialisme. Di antara pesantren salaf terkenal yang tetap mempertahankan sistem salaf adalah Sarang Rembang, Pondok Pesantren Sidogiri Pasuruan, Pondok Pesantren Langitan Tuban, dan Pondok Pesantren Lirboyo Kediri. Sedangkan pesantren modern selalu peka terhadap perubahan zaman seperti penggunaan teknologi informasi dengan pemanfaatan jaringan internet sebagai media belajar bagi santri dan berperan bukan saja dalam bidang pendidikan tetapi juga dalam aspek lainnya. Pondok Pesantren Modern berpandangan filsafat rekontruksionisme, progresivisme, dan rasionalisme. Diantara pondok pesantren modern yang terkenal adalah pondok modern Gontor dan Zaitun Indramayu.
\end{abstract}

Kata Kunci: Pondok Pesantren; Tradisional; Modern; Filsafat

\begin{abstract}
Philosophy and education have a very close relationship so that properly thinkers of philosophy respond to various problems regarding education include the education system in pesantren. This journal is intended to dissect and explore the education system of pondok pesantren both traditional and modern pesantren. Searching a philosophical foundation within it to be able to understand the deepest meaning of an education system in pesantren. Traditional pesantren organizes non-classical Islamic education with bandongan and sorogan methods in learning classical books (yellow books) by ulama in middle ages. The traditional pesantren holds the philosophy of perennialism, idealism, and essentialism. Among the famous traditional pesantren that maintain the salaf system are Sarang Rembang, pondok pesantren of Sidogiri Pasuruan, pondok pesantren of Langitan Tuban, and pondok pesantren of Lirboyo Kediri. Whereas modern pesantren always consideratein changing times such as the use of information technology with the use of the internet as a medium of learning for santri and play a role not only in education but also in other aspects. Modern pesantren holds philosophy of reconstructionism, progressivism, and rationalism. Among the famous modern pesantren are the modern pondok of Gontor and Zaitun Indramayu.
\end{abstract}

Keywords: Pondok Pesantre; TraditionaL; Modern; Philosophy. 


\section{INTRODUCTION}

One of the education institutions in Indonesia that has its own characteristics and different from other education institutions is pesantren. This institution was born, grew, and developed a long time ago. In fact, since other educational institutions are not yet known at Indonesia, pesantren had arrived earlier. That is why, pesantren is on generally seen as an authentic educational institution (indigenous) Indonesia (Heriyudanta, 2016: 146). These characteristics, for example, according to K.H. Yusuf Hasyim, leader of the Tebuireng Jombang pesantren, is a pesantren specialty which is functional as an institution which includes the functions of education, da'wah, society, and even struggle in the colonial period (Heriyudanta, 2016: 148).

In the midst of transparency informationand the incessant process of transformation of Islamic education values, pondok pesantren are expected to fortify movement and development that causes global problems overand life atmosphere strange increasingly. Moreover, the increasing of plurality life that more complex. All this raises anxiety not only among educators, officials, observers of life, but also felt by all levels of society (Muhmidayeli' 2007: 187). The rapid development of education needs and demands of technological science is increasing, pesantren according to its function is in a dilemmatic position. First, pesantren remain in its orthodox position, which is closing itselves from outside influences which are considered to pollute them as agents of moral force for the society. Second, pesantren is required to keep abreast of the times and be open to outside influences.

Philosophy and education have a very close relationship so properly philosophy thinkers respond to various problems regarding education, including education in pesantren. In pesantren education there are two models of the education system, namely the traditional pesantren education system and the modern pesantren education system. Essentially, this happened due to the expansion of modern education in the style of the Dutch colonialists at the time, which was then by some of pesantren who wanted continuity and the continuity to be responded by refusing while imitating.

Educational philosophy has many doctrines. The philosophy of education can be used to dissect and explore the education system of pondok pesantren both traditional and modern pesantren. Researcher specializes in the issue of pesantren to try and to find a philosophical foundation within it to be able to understand the deepest meaning of an education system in pesantren.

\section{RESEARCH METHODS}

This research uses a qualitative approach. This type of research is a case study. Qualitative research is an approach in conducting research-oriented to natural phenomena or symptoms. Qualitative research begins with the assumption of using an interpretation framework that shapes or influences studies related to the meaning 
imposed by individuals or groups on a social or human problem (Batubara, 2017: 97-98).

Sources of data from this study include primary and secondary data. Data that has been taken were analyzed by linking the answers given by respondents with an existing literature review.

\section{DISCUSSION}

\section{History of the Origin of Pondok Pesantren in Indonesia}

Sunan Gresik or Syaikh Maulana Malik Ibrahim was the first person who found a pengajian institution as an ancestor of the establishment of a pesantren as a place to educate santri. This effort began along with the collapse of the throne of Majapahit authority. There are several opinions about the origin and background of pesantren in Indonesia. First, the opinion which states that pesantren is rooted in the Islamic tradition itself, namely the tradition of tarekat. This view is related to the fact that the spread of Islam in Indonesia was initially most known in the form of tarekat activities led by kyai. One of the activities of the tarekat is to hold suluk, to worship in the mosque under the guidance of the kyai. For this purpose, the kyai provides special rooms to accommodate the santri to the left and right of the mosque. The participants of the tarekat in addition to being taught the practices of the tarekat are also taught religious books in various branches of Islamic knowledge. Their activity was then called pengajian. Next developments, this pengajian institution grew and developed into a pesantren institution (Abdul Aziz, et al., 1994: 103).

The second opinion, Muhaimin (1993: 298-299) states that the presence of pesantren in Indonesia was inspired by Kuttab educationinstitutions, namely education institutions during the Umayyah kingdom which were originally only a vehicle or a reading and writing institution with a halaqah system. In the next stage the institution went through rapid development, because it was supported by community contributions and plans that had to be obeyed by educators and students. Hanun (1999: 184) this opinion is almost the same as the opinion stated that the pesantren was adopted from the Middle East Islamic education institutions, namely al-Azhar in Cairo, Egypt.

The third opinion, the existing pesantren is a takeover of the pesantren system of Hindus in the archipelago at the pre-Islamic era. This institution is intended as a place to teach the doctrines of Hinduism as well as a place to foster cadres who spread the religion (Abdul Aziz, et al., 1994). Dhofier (1997: 10) pesantren is a historical creation of the nation's children after experiencing cultural contact with pre-Islamic culture. Pesantren is an Islamic education system that has similarities with the Hindu-Buddhist education system. Pesantren are equated with mandalas and dormitories in the treasury of 
pre-Islamic education institutions. Pesantren is a group of independent communities that initially isolate themselves in a place far from the urban center (mountains).

Departemen Agama RI (1984/1985: 668) regarding the history of the establishment of the first or oldest pesantren in Indonesia there were differences of opinion among researchers, both the name of the pesantren and the year of its establishment. Based on the results of data collection conducted by the Department of Religion in 1984-1985, information was obtained that the oldest pesantren in Indonesia was the Jan Tanpes II Pesantren in Pamekasan Madura, which was built in 1762. But the data was rejected by Mastuhu. He rejected this information within reasons that before the existence of the Jan Tepes II Pesantren, there must have been an older Jan Tanpes I Pesantren.

Meanwhile, according to Martin Van Bruinessan as quoted by Abdullah Aly that the Tegalsari pesantren, one of the villages in Ponorogo, East Java, is the oldest pesantren in Indonesia, which was founded in $1742 \mathrm{M}$. The distinction of opinions because of the few of pesantren historical records that explain the existence of pesantren.

2. Pondok Pesantren Education

The word "pondok" (room, hut, small house) is used in Indonesian with an emphasis on the simplicity of the building. The word pondok comes from Arabic namely funduq which means hotel, hostel, house, and simple residence. Whereas the word "pesantren" comes from the word santri which gets an additional prefix "pe" and a suffix "an" which shows the place. Pesantren means place for santri (Muhmidayeli, 2007: 189). The bundle word of santri comes from the syllables "sant" (good human) and "tra" (helpful), so the word pesantren can mean a place of good human education. Prof. Jhon believes that the term santri, comes from Tamil, which means the teacher of ngaji. C.C. Berg argues that the term is from shastri which in Indian means people who know the sacred books of Hinduism.

Yasmadi (2002: 61-62) while the origin of the word "santri", in the view of Nurcholish Madjid can be seen from two opinions. First, the opinion that says "santri" comes from the words "sastri", a word from Sanskrit which means literate. This opinion, according to Nurcholish Madjid, is based on the santri being a literary class for Javanese who try to absorb into religion through books written in Arabic. Second, the opinion which states that the words of santri actually come from Javanese, from the word "cantrik" which means someone who always follows a teacher where the teacher goes to reside.

Besides pesantren, Islamic education institutions that resemble those still exist. In Aceh it is called rangkang and dayah, while in West Sumatra it is called 
surau. There are some characteristics that are generally owned by pondok pesantren as education institutions as well as social institutions that are informally involved in community development in general. Zamakhsyari Dhofier proposed five elements of pondok pesantren which included: kyai, mosque, pondok, santri, and teaching classical books (Dhofier, 1982).

a. Kyai. Qomar (2005: 56), kyai is a title by a religious expert, pondok pesantren leader, teacher in the framework of lectures, lecturers and interpreters about important occurences in the surrounding community. Kyai is the most influential figure in pesantren. Usually the kyai is the founder of the pesantren, so that the growth of the pesantren depends on the ability of the kyai itself.

b. The Mosque. Madjid (2000: 43) the mosque is derived from the Arabic "sajada-yasjudu-sujuuan-masjidan" which means the place of prostration or any room used for worship. The function of the mosque in the pesantren is not only as a place for prayer, but as a center of thought for all the necessity of santri including education and teaching.

c. Dormitory or Pondok. Pesantren in general are often also called traditional Islamic education institutions where all the santri live together and study under the guidance of a kyai. This santri hostel is located in a pesantren complex which consist of kyai-kyai, mosques, study rooms and other religious activities. This phenomenon distinguishes pesantren from other education systems.

d. Santri. Santri are students who study in pesantren. The existence of kyai is usually relate to the presence or absence of santri in pesantren. In general, santri undertake independent living activities such as cooking, washing, and other activities.

e. Pengajian of the Yellow Book. Another element that has become a tradition at pesantren is the teaching of classical Islamic books written by previous great ulama-ulama about various types of Islamic religious knowledge and Arabic. The classic books which was taught in pesantren are mainly based on doctrine of Shafi'iyah (Madjid, 2001: 39).

Even though it is said to be an element of a pesantren, apparently not all pesantren have these five elements. There were those who judged that at least the pesantren had three elements, namely, kyai, santri, and mosque. The pesantren element in the form of a triangle illustrates that an education process does not always require complete facilities.

3. Traditional Pesantren Education System in the Perspective of Educational Philosophy

Wahyoetomo (1997: 83) the traditional pesantren education system is a pesantren institution that maintains the teaching of classical books as the main of 
education. In relevance with the understanding of traditional pesantren, observers of the pesantren give different definitions. According to Husni Rahim, traditional pesantren are pesantren that organize non-classical Islamic education using bandongan and sorogan methods in studying classical books (yellow books) by ulama-ulama at middle ages. Whereas Assegaf provides criteria for traditional pesantren that are non-classical, traditional and teaches pure Islamic (Assegaf, 2005). Besides the same criteria as the two pesantren observers above, Asmani added that his culture and paradigm of thinking were dominated by classic terms, such as excessive tawadlu', zuhud, qana'ah, blessings or afterlife oriented (Al Hana, 2012: 204).

Al Hana, (2012), in the profile of pesantren Mu'adalah, the Ministry of Religion defines salaf as "old" or "traditional" and salaf pesantren is a pesantren that organizes lessons using the traditional approach, as has been took place since the beginning of its growth. Learning Islamic sciences is undertaken individually or in groups with a concentration of classical Arabic books. The investigating is not based on a time, but based on the completion of the book being studied. With the completion of one particular book, santri can rise to the level of the book with a higher difficulty level, and so on. Ridwan Nasir defines salaf pesantren with pesantren in which there is salaf education (weton and sorogan) and the salaf classical system (madrasah). Yasmadi (2002: 67) weton is a pengajian whose initiative comes from the kyai himself in determining the place, time, and book. While sorogan, pengajian that was a request from a person or several santri to their kyai to be taught a particular book. The pengajian with the sorogan system is usually given to santri-santri who are quite advanced, especially those who are interested in becoming preachers or kyai.

In general, the emotional relationship of the kyai-santri in traditional pesantren is much closer than modern pesantren. This is because the kyai becomes a central figure, as a character educator, spiritual guide and teacher of religious knowledge. Famous Pesantren that maintain the Salaf system are Sarang Rembang, pondok pesantren of Sidogiri Pasuruan, pondok pesantren of Langitan Tuban, pondok pesantren of Lirboyo Kediri.

In the perspective of educational philosophy, the traditional pesantren education system (salaf) are as follow: First, traditional pesantren teach purely the religion of Islam with reference to the classic books (yellow books) of ulama at the middle ages with the system of sorogan, bandongan and wetonan. From this point of view, the traditional pesantren has a philosophy of perennialism in which its view is to preserve the product (results) of the previous ulama's ijtihad, the way in place, should not jump from the great book. The ability of santri to master the science of religion is based on the mastery of certain books with different levels of difficulty, so that the length of time can not be used as a 
measure to determine the level of scientific knowledge of santri. The curriculum used is subject-oriented (subject centered). Second, the kyai becomes a central figure, as a character educator, spiritual guide and teacher of religious studies. From this point of view the traditional pesantren holds the philosophy of essentialism. Essentialism has provided a formula for the rationale for how a learning method that is most effective and efficient, is teacher-centered education. Third, the granting of "diplomas" (kya is recognition/belief in santri) for certain Islamic knowledge abilities is still very dominant and formal diplomas are not a priority for santri, because most pesantren do not issue diplomas, whereas santri with sincerity come in the pesantren without the diploma. This is because its main purpose is only to seek the pleasure of Allah. Through this side the traditional pesantren holds the philosophy of essentialism. Essentialism emphasizes the quality and not concerned with physical. Fourth, the culture and paradigm of thinking are dominated by classical terms, such as excessive tawadlu', zuhud, qana'ah, barakah or the afterlife oriented. From this side, the traditional pesantren has a perennial idealism philosophy.

4. Modern Pesantren Education System in the Perspective of Educational Philosophy

Wahyudin (2014: 92), modern pesantren education system is a pesantren institutional system that is managed in a modern manner both in aspects of administration, teaching system and curriculum. The word modern, by Abbudin Nata is interpreted as the latest or the most recent. Furthermore the word modern is also closely related to the word modernization which means renewal or tajdid in Arabic.

Modern pesantren (khalaf or asriyah) are pesantren that have carried out reformation (modernization) in education, institutions, thoughts and functions. The khalaf pesantren has included general lessons in madrasah that have been developed or opened types of public schools within the pesantren environment. The education system in modern pesantren includes at least curriculum and methodology. Renewal (modernization) of the curriculum is carried out by continuing to provide Islamic teachings, while including general subjects as educational substance (Wahyudin, 2014).

The application of this modern learning system is especially evident in the use of learning classes in the form of both madrasah and schools. In the aspect of institution management, modern pesantren tend to consolidate institution organizations, especially the leadership and management aspects. Modern pesantren besides having a traditional role, at least it is also a center for health counseling, a center for technology development, and an effort to save the environment, and more important become a center for community economic empowerment. 
The position of the kyai as the coordinator of the learning process and as a class teacher is not a central figure. Modern pesantren emphasizes more on rationality, future orientation, life competition and technology mastery. Among the famous modern pesantren are the modern pondok of Gontor and Zaitun Indramayu.

In the perspective of educational philosophy, the modern pondok pesantren education system are as follow: First, transparency of values originating from outside is always done by modern pondok pesantren. Pesantren are always sensitive toward changing times such as the use of information technology with the use of the internet as a medium of learning for santri and act not only in the field of education but also in other aspects. Activities become moresolid and society oriented. From this side the modern pondok pesantren holds the philosophy of Reconstructionism where its view is transparency, responsive, and views that education is an institution that makes social, economic, and political changes in society. Second, the curriculum used is the national curriculum by providing Islamic religious teachings, including general subjects as educational substance especially emphasizing mastery in foreign languages (Arabic and English). The use of learning classes in the form of madrasah and schools with teaching methods applied the methods of question and answer, memorization, socio-drama, study tours, lectures, modules, discussions and seminars. From this side the modern pondok pesantren holds the philosophy of Progressivism where its view of the curriculum is that the curriculum must be flexible. Third, the position of the kyai as the coordinator of the learning process and as a teacher in the classroom is not a central figure. From this side the modern holds the philosophy of Progressivism where its view of the teacher's role is not direct but to provide guidance to children. Fourth, bending with terms tawadlu', barakah, and the like. Emphasis on rationality, future orientation, life competition, and mastery of technology. From this side the Modern pondok pesantren holds the philosophy of Rationalism.

\section{CLOSING}

Regarding the origins and background of pesantren in Indonesia there were differences of opinion among historians. Some say that pesantren are potent rooted in Indonesia, which is considered a characteristic Indonesian institution. The second opinion, said, pesantren came from the Hindu education system in India. The third opinion, said, the pesantren is oriented to the Islamic education system in Mecca and Medina and other Middle Eastern Countries. The traditional pesantren education system is a pesantren institution that maintains the teaching of classical books as the main of education. Traditional pesantren is a pesantren which organizes non-classical Islamic education using the bandongan and sorogan method in studying classical books (yellow books) by ulama at middle ages. The traditional 
pesantren holds the philosophy of perennialism, idealism, and essentialism. Among the famous traditional pesantren that still maintain the salaf system are Sarang Rembang, Pondok Pesantren of Sidogiri Pasuruan, Pondok Pesantren of Langitan Tuban, Pondok Pesantren of Lirboyo Kediri.

Whereas the modern pesantren education system is a pesantren institution system that is managed in a modern manner both in terms of administration, teaching system and curriculum. The word "modern", by Abbudin Nata is interpreted as the latest or the most recent. Furthermore the word "modern" is also closely related to the word modernization which means renewal or tajdid in Arabic. Among the famous modern pesantren are the modern pondok of Gontorand Zaitun Indramayu. This model pondok emphasizes on mastery in foreign languages (Arabic and English), there is no study of the yellow books, the curriculum adopts a modern curriculum, flexible of things tawadlu', barakah and the like. Emphasis on rationality, future orientation, life competition and technologic mastery. Modern pesantren holds philosophy of reconstructionism, progressivism, and rationalism.

\section{REFERENCE}

Aly, Abdullah. 2011. Pendidikan Islam Multikultural di Pesantren: Telaah Terhadap Kurikulum Pondok Pesantren Modern Islam Assalam Surakarta, cet. ke-1. Yogyakarta: Pustaka Pelajar.

Asrohah, Hanun. 1999. Sejarah Pendidikan Islam, cet. ke-1. Jakarta: Logos Wacana Ilmu

Assegaf, Abd. Rahman. 2005. Politik Pendidikan Nasional,Pergeseran Kebijakan Pendidikan Agama Islam dari Proklamasi ke Reformasi. Yogjakarta: Kurnia Kalam

Aziz, Abdul. 1994. Ensiklopedi Islam IV. cet. ke-2, Jakarta: Ichtiar Baru Van Hoeve

Batubara, J. (2017). Paradigma Penelitian Kualitatif dan Filsafat Ilmu Pengetahuan dalam Konseling.Jurnal Fokus Konseling. 3(2): 95-107.

Departemen Agama RI., 1984/1985. Nama dan Data Potensis Pondok-Pondok Pesantren Seluruh Indonesia. Jakarta: Depag RI.,

Dhofier, Zamakhsyari. 1982. Tradisi Pesantren: Studi tentang Pandangan Hidup Kyai. Jakarta: LP3ES

Dhofier, Zamakhsyari. 1997. Tradisi Pesantren: Studi tentang Pandangan Hidup Kyai. Cet. ke-7. Jakarta: LP3ES

Heriyudanta, Muhammad. 2016. Modernisasi Pendidikan Pesantren Perspektif Azyumardi Azra. Mudarrisa, Jurnal Kajian Pendidikan Islam, 8(1): 145-172.

Madjid, Nurcholish. 2000. Islam, Doktrin dan Peradaban, Sebuah Telaah Kritis tentang Masalah Keimanan, Kemanusiaan dan Kemodernan. Jakarta: Paramadina 
Madjid, Nurcholish. 2001. Islam Kerakyatan dan Keindonesiaan, cet. ke-3. Bandung: Mizan

Mastuhu, 1994. Dinamika Sistem Pendidikan Pesantren: Suatu Kajian Tentang Unsur dan Nilai Sistem Pendidikan Pesantren. Jakarta: INIS

Muhaimin. 1993. Pemikiran Pendidikan Islam. cet. ke-3. Bandung: Tri Genda Karya

Muhmidayeli. 2007. Membangun Paradigma Pendidikan Islam. Pekanbaru: Program Pascasarjana UIN Suska Riau

Qomar. 2005. Pesantren dan Tranformasi Metodologi Menuju Demokratisasi Institusi. Jakarta: Erlangga

Rudi Al Hana. 2012. Perubahan-Perubahan Pendidikan di Pesantren Tradisional (Salafi), Tadris. 7(2): 198-213

Wahyoetomo. 1997. Perguruan Tinggi Pesantren: Pendidikan Alternatif Masa Depan. Jakarta: Gema Insani Press

Wahyudin, 2014. Relevansi Pendidikan Pesantren dengan Pendidikan Modern. NIZHAM. 3(02): 88-106

Yasmadi, 2002. Modernisasi Pesantren, Kritik Nurcholish Madjid terhadap Pendidikan Islam Tradisional. Jakarta: Ciputat Press 